\title{
Trefoil Factor Family Member 2 Expression as an Indicator of the Severity of the High-Fat Diet-Induced Obesity
}

\author{
Abdelaziz Ghanemi ${ }^{1,2}$ (D), Mayumi Yoshioka ${ }^{1}(\mathbb{D})$ and Jonny St-Amand ${ }^{1,2, *(\mathbb{D})}$ \\ 1 Functional Genomics Laboratory, Endocrinology and Nephrology Axis, CHU de Québec-Université Laval \\ Research Center, 2705 Boul. Laurier, Québec, QC G1V 4G2, Canada; \\ Abdelaziz.Ghanemi@crchudequebec.ulaval.ca (A.G.); mayumi.yoshioka@crchudequebec.ulaval.ca (M.Y.) \\ 2 Department of Molecular Medicine, Faculty of Medicine, Laval University, Québec, QC G1V 0A6, Canada \\ * Correspondence: jonny.st-amand@crchudequebec.ulaval.ca; Tel.: +1-(418)-654-2296; Fax: +1-(418)-654-2761
}

Citation: Ghanemi, A.; Yoshioka, M.; St-Amand, J. Trefoil Factor Family Member 2 Expression as an Indicator of the Severity of the High-Fat Diet-Induced Obesity. Genes 2021, 12, 1505. https://doi.org/10.3390/ genes12101505

Academic Editor: Thangiah Geetha

Received: 15 September 2021

Accepted: 24 September 2021

Published: 26 September 2021

Publisher's Note: MDPI stays neutral with regard to jurisdictional claims in published maps and institutional affiliations.

Copyright: (c) 2021 by the authors. Licensee MDPI, Basel, Switzerland. This article is an open access article distributed under the terms and conditions of the Creative Commons Attribution (CC BY) license (https:// creativecommons.org/licenses/by/ $4.0 /)$.

\begin{abstract}
Trefoil Factor Family Member 2 (TFF2) belongs to TFF family peptides that includes TFF1, TFF2, TFF3. TFF2 is mainly known for its roles in the mucosal protection. In the context of obesity and high fat diet (HFD), Tff2 has been characterized as a HFD-induced gene. The knock-out of Tff2 in mice lead to the protection from HFD-induced obesity with a metabolic profile towards a negative energy balance. Such HFD-specific expression gives Tff2 a pattern worth exploring in biomedical research. Indeed, measuring TFF2/TFF2/Tff2 expression in biological samples following the ingestion of high-fat diet reflects the biological "responsiveness" to the lipids ingestion and would reflect the severity of obesity establishment afterwards. Such property could be explored for instance to screen animal models, evaluate the predisposition to HFD-induced obesity as well as in biomedical and clinical applications. Results might advance obesity research especially in terms of understanding lipid-induced signals, appetite control and adiposity storage.
\end{abstract}

Keywords: Trefoil Factor Family Member 2; expression; indicator; high-fat; diet; obesity

Obesity represents a growing challenge for health professionals and officials which represents a risk factor for a variety of diseases (including during the ongoing COVID-19 crisis [1-4]) and various diseases [5-8]; and it is also considered a disease itself [9]. It also represents a huge economic burden $[10,11]$. The main challenging pattern facing the development of obesity research and therapies is the limited understanding of its molecular and cellular pathways [12,13]. Therefore, providing new molecular tools to explore obesity, its development and its pathogenesis remains of a high importance. Within this piece of writing, we describe a potential application of trefoil factor family member 2 (TFF2/Tff2) expression pattern related to high fat (HF) diet (HFD).

TFF2 belongs to TFF family peptides that includes TFF1, TFF2 and TFF3 [14,15]. TFF2 is mainly known for its roles in the mucosal protection including in the gastrointestinal tracts [15-17], but it is also implicated in a variety of functions including anti-inflammatory process [18], tissue repair [19] and cancer [20]. Interestingly, recent studies have highlighted metabolic implications of TFF2 especially in the context of obesity and HFD. Indeed, using functional genomics approaches [21], Tff2 has been characterized as a HF-induced gene in mice intestinal mucosa. The HF specificity has been revealed through an experimental design that used fasted status (instead of low-fat) as a control to which both HF and low-fat fed mice have been compared [22,23]. Indeed, the gene expression, studied based on serial analysis of gene expression and confirmed with microarray analysis, revealed that in the intestinal mucosa the Tff2 is overexpressed following the ingestion of a HF meal and not a low fat meal [22,23]. Therefore, highlights Tff2 as a HF specifically-induced gene.

In order to elucidate the implications of TFF2 in the context of obesity, and more specifically in the HF-diet obesity, Tff2 knock-out (KO) mice were challenged with HFD [24]. The study has shown that the Tff2 $\mathrm{KO}$ mice, compared to the wild-type (WT) mice, are in fact 
protected from HFD-induced obesity with an increased lipids excretion as well [24] which correlates with the exacerbation of weight loss by TFF2 deficiency shown by Judd et al. [25]. Moreover, the metabolic exploration of key metabolic tissues of these mice revealed mechanisms that explain such protection. Indeed, Tff2 $\mathrm{KO}$ mice have a metabolic phenotype towards an increased energy expenditure with reduced energy storage [26]. In our recent review [27], we have detailed a hypothesis that aims to explain how HFD induces Tff2 overexpression and at the same time the $\mathrm{KO}$ of this same gene, Tff2, lead to the protection from the HF-diet-induced obesity via metabolic changes. Briefly, the TFF2 expression would be a signal leading to metabolic adaptation, which facilitates the lipid digestion, anabolism and storage. Therefore, HFD would induces its overexpression to facilitate the digestion and the anabolism of lipids coming from such HFD, whereas Tff2 KO would deprive the metabolic machinery from molecular tools required to use the ingested lipids through an increased lipid absorption and storage, which leads to a protection from the HFD-induced obesity. It is worth pointing that gut microbiota, which contributes significantly to metabolic disorders [28] including obesity [29], impaired glucose [30] and lipid metabolism [31], can also be altered by diets [32,33] including HFD [34,35]. In the obesity context, the interactions between TFF2 and gut microbiota [36] could be involved in the mechanisms of HFD-induced obesity. Therefore, TFF2 would represent a molecular mechanistic link between HFD and obesity development [27].

Based on such properties of Tff2 induction by HDF and its implications in HFDinduced obesity, potential applications can derive from and range from biomedical research to clinical practice (Figure 1). The concept would be to challenge biological systems (animals, cell cultures, isolated tissues, etc.) with HFD followed by the measure of Tff2 or TFF2 expression in the intestinal mucosa [22,23], blood [37] or other tissues [38-40]. This could allow for instance to evaluate the "predisposition" to develop HFD-induced obesity based on the expression intensity of TFF2/Tff2 following HFD. Obesity animal models are diverse [41], among them different species have been used to generate animal models of HFD-induced obesity. Within this context, measuring Tff2 expression following the ingestion of a HFD could represent a standard approach to compare the different animal models and therefore optimize the selections of the one(s) suitable to build the obesity model for the experiments depending on the experimental contexts and goals. The same principle can be applied to select, following a genetic modifications (KO, overexpression, etc.), the animals to be used for breeding and used for the obesity-related studies.

For clinical perspectives, we can estimate the risk of HFD-induced obesity in individuals by the same approaches. For the pharmacological studies and research applications, obesity drugs can be tested as a purpose to reduce Tff 2 expression and therefore mimic $T f f 2 \mathrm{KO}$ and lead to a metabolic profile similar to the one seen in Tff $2 \mathrm{KO}$ mice described above (protection for HFD-induced obesity) $[24,26]$. Therefore, adapt the individuals' diet, not only in terms of lipids content but even depending of lipids types. Indeed, for the pharmacological studies and research applications such measures can be used also to adapt a diet, test a drug or evaluate a treatment in the context of HFD-induced obesity. This might be achieved by measuring TFF2/Tff2 expression depending on the type of lipids that can also be tested in cells to study the molecular changes. Therefore, the studies would go deeper by comparing, among the HFD, the different types of lipids and test a variety of combination to gain new knowledge on links between diets composition and its ability to induce obesity (through Tff2 expression) especially while comparing diets that have similar number of calories. Within this context, the variety of functional genomics methods $[42,43]$ allowing to measure the Tff2 expression are molecular tools that provide a flexibility to such applications as well.

We believe that the measure of TFF2/TFF2/Tff2 expression level in response to HFD could expand our cellular and molecular understanding of obesity and strengthen therapeutic research especially that TFF2 could be a lipid-specifically induced signal we are yet to confirm to complete the puzzle of fat-induced signals, appetite control and adiposity storage; all key elements in energy homeostasis and obesity development. 


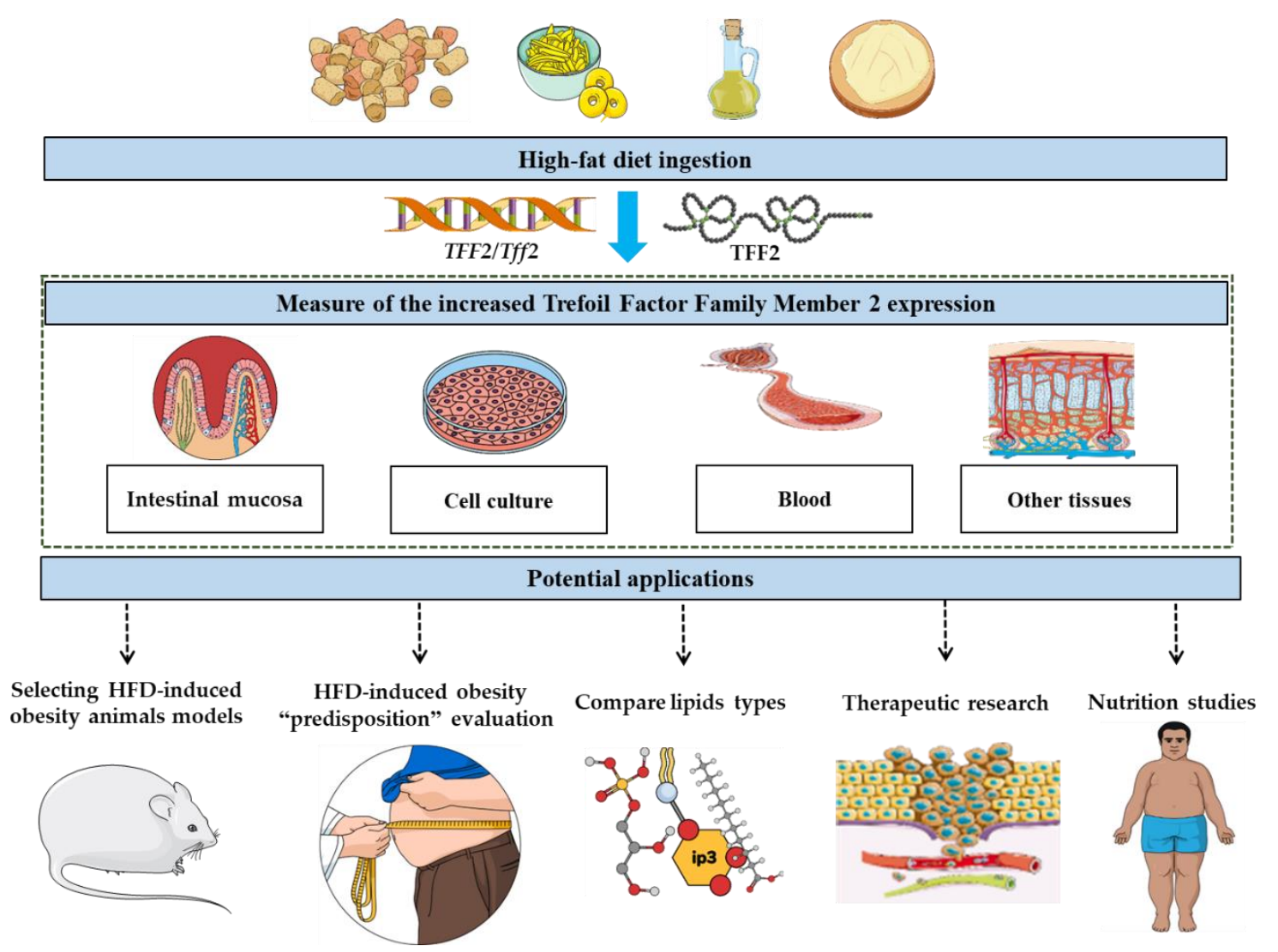

Figure 1. Measuring Trefoil Factor Family Member 2 (TFF2/TFF2/Tff2) expression in biological samples following the ingestion of high-fat diet reflects the biological "responsiveness" to the lipids ingestion and would reflect the severity of obesity establishment. Such property could be explored for instance to screen animal models, evaluate the predisposition to high-fat diet-induced obesity as well as in biomedical and clinical applications.

Author Contributions: A.G. designed the manuscript structure and wrote it. A.G., M.Y. and J.S.-A. discussed the content and exchanged ideas and suggestions (concepts to add, the figure, references selection, etc.) throughout the writing process, edited and critically revised the paper. J.S.-A. gave the final approval for the version to be published. All authors have read and agreed to the published version of the manuscript.

Funding: This work received no external funding.

Institutional Review Board Statement: Not applicable.

Informed Consent Statement: Not applicable.

Data Availability Statement: Not applicable.

Acknowledgments: Abdelaziz Ghanemi received a scholarship under the Merit Scholarship Program for foreign students from the Ministry of Education and Higher Education of Quebec, Canada. The Fonds de recherche du Québec-Nature et technologies (FRQNT) is responsible for managing the program (Bourses d'excellence pour étudiants étrangers du Ministère de l'Éducation et de l'Enseignement supérieur du Québec, Le Fonds de recherche du Québec-Nature et technologies (FRQNT) est responsable de la gestion du programme). Abdelaziz Ghanemi received the scholarship «Bourse Tremplin -Stage en milieu de pratique» (Internship scholarship) from the Fonds de recherche du Québec-Sante (FRQS), Quebec, Canada. Figure 1 was created using images from https:/ / mindthegraph.com/ (accessed on 31 August 2021) and http:/ / smart.servier.com (accessed on 31 August 2021). Servier Medical Art by Servier is licensed under a Creative Commons Attribution 3.0 Unported License.

Conflicts of Interest: The authors declare that there is no conflict of interest. 


\section{References}

1. Albashir, A.A.D. The potential impacts of obesity on COVID-19. Clin. Med. 2020, 20, e109-e113. [CrossRef]

2. Petrakis, D.; Margină, D.; Tsarouhas, K.; Tekos, F.; Stan, M.; Nikitovic, D.; Kouretas, D.; Spandidos, D.A.; Tsatsakis, A. Obesity-A risk factor for increased COVID-19 prevalence, severity and lethality (Review). Mol. Med. Rep. 2020, 22, 9-19. [CrossRef] [PubMed]

3. Ghanemi, A.; Yoshioka, M.; St-Amand, J. Will an obesity pandemic replace the coronavirus disease-2019 (COVID-19) pandemic? Med. Hypotheses 2020, 144, 110042. [CrossRef] [PubMed]

4. Ghanemi, A.; Yoshioka, M.; St-Amand, J. Coronavirus Disease 2019 (COVID-19) Crisis: Losing Our Immunity When We Need It the Most. Biology 2021, 10, 545. [CrossRef]

5. Ghanemi, A.; Yoshioka, M.; St-Amand, J. Regeneration during Obesity: An Impaired Homeostasis. Animals 2020, 10, 2344. [CrossRef] [PubMed]

6. Zachariae, C.; Skov, L. Obesity as a risk factor for psoriasis. J. Eur. Acad. Dermatol. Venereol. 2020, 34, 915-916. [CrossRef] [PubMed]

7. Mandviwala, T.; Khalid, U.; Deswal, A. Obesity and Cardiovascular Disease: A Risk Factor or a Risk Marker? Curr. Atheroscler. Rep. 2016, 18, 21. [CrossRef]

8. De Pergola, G.; Silvestris, F. Obesity as a major risk factor for cancer. J. Obes. 2013, 2013, 291546. [CrossRef]

9. Ghanemi, A.; St-Amand, J. Redefining obesity toward classifying as a disease. Eur. J. Intern. Med. 2018, 55, 20-22. [CrossRef]

10. Withrow, D.; Alter, D.A. The economic burden of obesity worldwide: A systematic review of the direct costs of obesity. Obes Rev. 2011, 12, 131-141. [CrossRef]

11. Tremmel, M.; Gerdtham, U.G.; Nilsson, P.M.; Saha, S. Economic Burden of Obesity: A Systematic Literature Review. Int. J. Environ. Res. Public Health 2017, 14, 435. [CrossRef] [PubMed]

12. Ghanemi, A.; Yoshioka, M.; St-Amand, J. Broken Energy Homeostasis and Obesity Pathogenesis: The Surrounding Concepts. J. Clin. Med. 2018, 7, 453. [CrossRef] [PubMed]

13. Ghanemi, A.; Yoshioka, M.; St-Amand, J. Obesity as a Neuroendocrine Reprogramming. Medicina 2021, 57, 66. [CrossRef] [PubMed]

14. Hoffmann, W. Trefoil Factor Family (TFF) Peptides and Their Diverse Molecular Functions in Mucus Barrier Protection and More: Changing the Paradigm. Int. J. Mol. Sci. 2020, 21, 4535. [CrossRef]

15. Braga Emidio, N.; Hoffmann, W.; Brierley, S.M.; Muttenthaler, M. Trefoil Factor Family: Unresolved Questions and Clinical Perspectives. Trends Biochem. Sci. 2019, 44, 387-390. [CrossRef]

16. Hoffmann, W.; Jagla, W.; Wiede, A. Molecular medicine of TFF-peptides: From gut to brain. Histol. Histopathol. 2001, 16, 319-334.

17. Taupin, D.; Podolsky, D.K. Trefoil factors: Initiators of mucosal healing. Nat. Rev. Mol. Cell Biol. 2003, 4, 721-732. [CrossRef]

18. Ghanemi, A.; Yoshioka, M.; St-Amand, J. Trefoil Factor Family Member 2 (TFF2) as an Inflammatory-Induced and AntiInflammatory Tissue Repair Factor. Animals 2020, 10, 1646. [CrossRef]

19. Ghanemi, A.; Yoshioka, M.; St-Amand, J. High-Fat Diet-Induced Trefoil Factor Family Member 2 (TFF2) to Counteract the Immune-Mediated Damage in Mice. Animals 2021, 11, 258. [CrossRef]

20. Ge, Y.; Ma, G.; Liu, H.; Lin, Y.; Zhang, G.; Du, M.; Wang, M.; Chu, H.; Zhang, H.; Zhang, Z. MUC1 is associated with TFF2 methylation in gastric cancer. Clin. Epigenet. 2020, 12, 37. [CrossRef]

21. Ghanemi, A.; Melouane, A.; Yoshioka, M.; St-Amand, J. Exercise and High-Fat Diet in Obesity: Functional Genomics Perspectives of Two Energy Homeostasis Pillars. Genes 2020, 11, 875. [CrossRef] [PubMed]

22. Yoshioka, M.; Bolduc, C.; Raymond, V.; St-Amand, J. High-fat meal-induced changes in the duodenum mucosa transcriptome. Obesity 2008, 16, 2302-2307. [CrossRef] [PubMed]

23. Mucunguzi, O.; Melouane, A.; Ghanemi, A.; Yoshioka, M.; Boivin, A.; Calvo, E.L.; St-Amand, J. Identification of the principal transcriptional regulators for low-fat and high-fat meal responsive genes in small intestine. Nutr. Metab. $2017,14,66$. [CrossRef] [PubMed]

24. De Giorgio, M.R.; Yoshioka, M.; Riedl, I.; Moreault, O.; Cherizol, R.G.; Shah, A.A.; Blin, N.; Richard, D.; St-Amand, J. Trefoil factor family member 2 (Tff2) KO mice are protected from high-fat diet-induced obesity. Obesity 2013, 21, 1389-1395. [CrossRef] [PubMed]

25. Judd, L.M.; Chalinor, H.V.; Walduck, A.; Pavlic, D.I.; Däbritz, J.; Dubeykovskaya, Z.; Wang, T.C.; Menheniott, T.R.; Giraud, A.S. TFF2 deficiency exacerbates weight loss and alters immune cell and cytokine profiles in DSS colitis, and this cannot be rescued by wild-type bone marrow. Am. J. Physiol Gastrointest. Liver Physiol. 2015, 308, G12-G24. [CrossRef]

26. Ghanemi, A.; Melouane, A.; Mucunguzi, O.; Yoshioka, M.; St-Amand, J. Energy and metabolic pathways in trefoil factor family member 2 (Tff2) KO mice beyond the protection from high-fat diet-induced obesity. Life Sci. 2018, 215, 190-197. [CrossRef]

27. Ghanemi, A.; Yoshioka, M.; St-Amand, J. Trefoil Factor Family Member 2: From a High-Fat-Induced Gene to a Potential Obesity Therapy Target. Metabolites 2021, 11, 536. [CrossRef] [PubMed]

28. Fan, Y.; Pedersen, O. Gut microbiota in human metabolic health and disease. Nat. Rev. Microbiol. 2021, 19, 55-71. [CrossRef]

29. Karlsson, F.H.; Tremaroli, V.; Nookaew, I.; Bergström, G.; Behre, C.J.; Fagerberg, B.; Nielsen, J.; Bäckhed, F. Gut metagenome in European women with normal, impaired and diabetic glucose control. Nature 2013, 498, 99-103. [CrossRef]

30. Wu, H.; Tremaroli, V.; Schmidt, C.; Lundqvist, A.; Olsson, L.M.; Krämer, M.; Gummesson, A.; Perkins, R.; Bergström, G.; Bäckhed, F. The Gut Microbiota in Prediabetes and Diabetes: A Population-Based Cross-Sectional Study. Cell Metab. 2020, 32, 379-390.e373. [CrossRef] 
31. Yu, Y.; Raka, F.; Adeli, K. The Role of the Gut Microbiota in Lipid and Lipoprotein Metabolism. J. Clin. Med. 2019, 8, 2227. [CrossRef]

32. Festi, D.; Schiumerini, R.; Eusebi, L.H.; Marasco, G.; Taddia, M.; Colecchia, A. Gut microbiota and metabolic syndrome. World J. Gastroenterol. 2014, 20, 16079-16094. [CrossRef]

33. Bibbò, S.; Ianiro, G.; Giorgio, V.; Scaldaferri, F.; Masucci, L.; Gasbarrini, A.; Cammarota, G. The role of diet on gut microbiota composition. Eur. Rev. Med. Pharmacol. Sci. 2016, 20, 4742-4749.

34. Yin, J.; Li, Y.; Han, H.; Chen, S.; Gao, J.; Liu, G.; Wu, X.; Deng, J.; Yu, Q.; Huang, X.; et al. Melatonin reprogramming of gut microbiota improves lipid dysmetabolism in high-fat diet-fed mice. J. Pineal Res. 2018, 65, e12524. [CrossRef]

35. Bisanz, J.E.; Upadhyay, V.; Turnbaugh, J.A.; Ly, K.; Turnbaugh, P.J. Meta-Analysis Reveals Reproducible Gut Microbiome Alterations in Response to a High-Fat Diet. Cell Host Microbe 2019, 26, 265-272.e264. [CrossRef]

36. Khoder, G.; Al-Yassir, F.; Al Menhali, A.; Saseedharan, P.; Sugathan, S.; Tomasetto, C.; Karam, S.M. Probiotics Upregulate Trefoil Factors and Downregulate Pepsinogen in the Mouse Stomach. Int. J. Mol. Sci. 2019, 20, 3901. [CrossRef]

37. Ishibashi, Y.; Ohtsu, H.; Ikemura, M.; Kikuchi, Y.; Niwa, T.; Nishioka, K.; Uchida, Y.; Miura, H.; Aikou, S.; Gunji, T.; et al. Serum TFF1 and TFF3 but not TFF2 are higher in women with breast cancer than in women without breast cancer. Sci. Rep. 2017, 7, 4846. [CrossRef] [PubMed]

38. Hoffmann, W. TFF2, a MUC6-binding lectin stabilizing the gastric mucus barrier and more (Review). Int. J. Oncol. 2015, 47, 806-816. [CrossRef] [PubMed]

39. May, F.E.; Semple, J.I.; Newton, J.L.; Westley, B.R. The human two domain trefoil protein, TFF2, is glycosylated in vivo in the stomach. Gut 2000, 46, 454-459. [CrossRef] [PubMed]

40. Cook, G.A.; Familari, M.; Thim, L.; Giraud, A.S. The trefoil peptides TFF2 and TFF3 are expressed in rat lymphoid tissues and participate in the immune response. FEBS Lett. 1999, 456, 155-159. [CrossRef]

41. Ghanemi, A.; Yoshioka, M.; St-Amand, J. Obese Animals as Models for Numerous Diseases: Advantages and Applications. Medicina 2021, 57, 399. [CrossRef] [PubMed]

42. Melouane, A.; Ghanemi, A.; Yoshioka, M.; St-Amand, J. Functional genomics applications and therapeutic implications in sarcopenia. Mutat Res. Rev. Mutat Res. 2019, 781, 175-185. [CrossRef] [PubMed]

43. Melouane, A.; Ghanemi, A.; Aubé, S.; Yoshioka, M.; St-Amand, J. Differential gene expression analysis in ageing muscle and drug discovery perspectives. Ageing Res. Rev. 2018, 41, 53-63. [CrossRef] 